\title{
Aki megtámadta Pearl Harbort - Iszoroku Jamamoto élete és katonai pályafutása m.ross
}

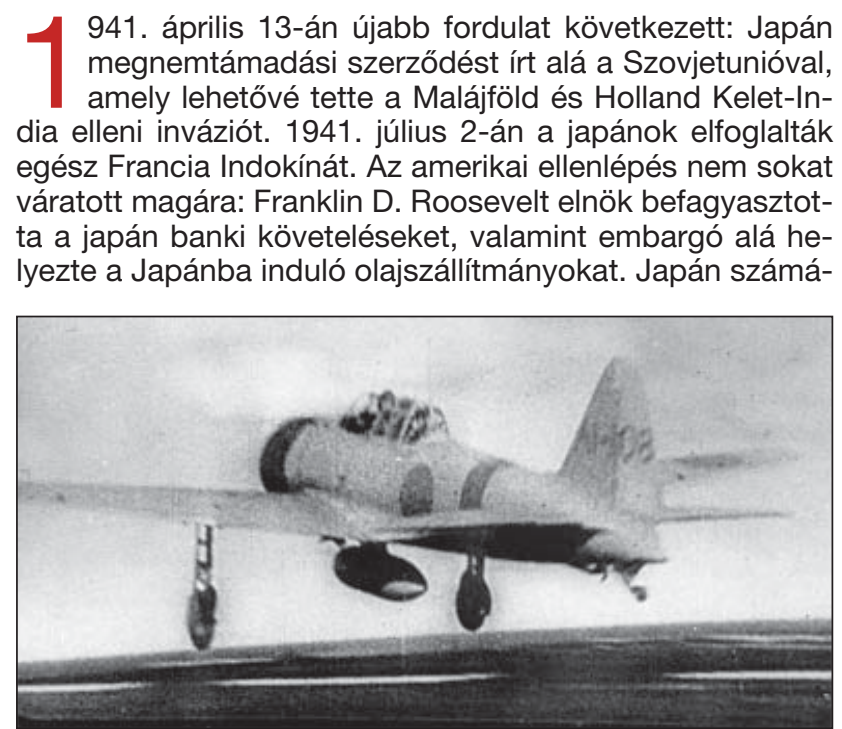

15. ábra. Az egyik támadó ZERO felszállása az AKAGI fedélzetéről ra ez végzetes döntésnek bizonyult, ugyanis kőolajkészletének 93\%-át a külföldi szállítmányok fedezték. Ezzel a nézeteltérések diplomáciai rendezése kudarcra volt ítélve: 1941. szeptember 6-án a kormány a háború mellett döntött (holott Konoye korábban még hajlott a megegyezésre), s ezt október 18-án az új miniszterelnök, Tojo Hideki is elfogadta, mint a japán terjeszkedés egyetlen módját.

A haditengerészet vezérkara azonban még mindig halogatta a döntést: nem merték vállalni a kockázatot. Túl nagy árnak tartották a két anyahajójuk bekalkulált elvesztését, hiszen legjobb esetben az amerikai csatahajóknak csak a kétharmadát pusztítják el. A konzervatívabb megoldást támogatták: a délen történő hódításokat, ami ellen az USA valószínűleg csak diplomáciai úton fog tiltakozni. Ezért Jamamoto drasztikus lépésre szánta el magát. Október 18-án Tokióba küldte Kemeto Kurisima kapitányt, aki így szólalt fel a vezérkar előtt:

„Jamamoto tengernagy úr ragaszkodik hozzá, hogy elfogadják a tervét. Engem bízott meg, hogy elmondjam: ha nem így történik, akkor az egyesített flotta föparancsnoka nem vállalja többé a felelösséget a birodalom biztonságáért. Ebben az esetben nem marad más lehetösége: egész tisztikarával együtt visszavonul."

16. ábra. A japán Mitsubishi A6M Zero (Zeke) vadász nem volt olyan erős felépítésű, mint az amerikai Hellcat vagy Corsair, de páratlan manőverező-képessége és erős fegyverzete miatt igen nagy hírnevet szerzett magának (A képen replika látható.) (Fotó: K.I.)

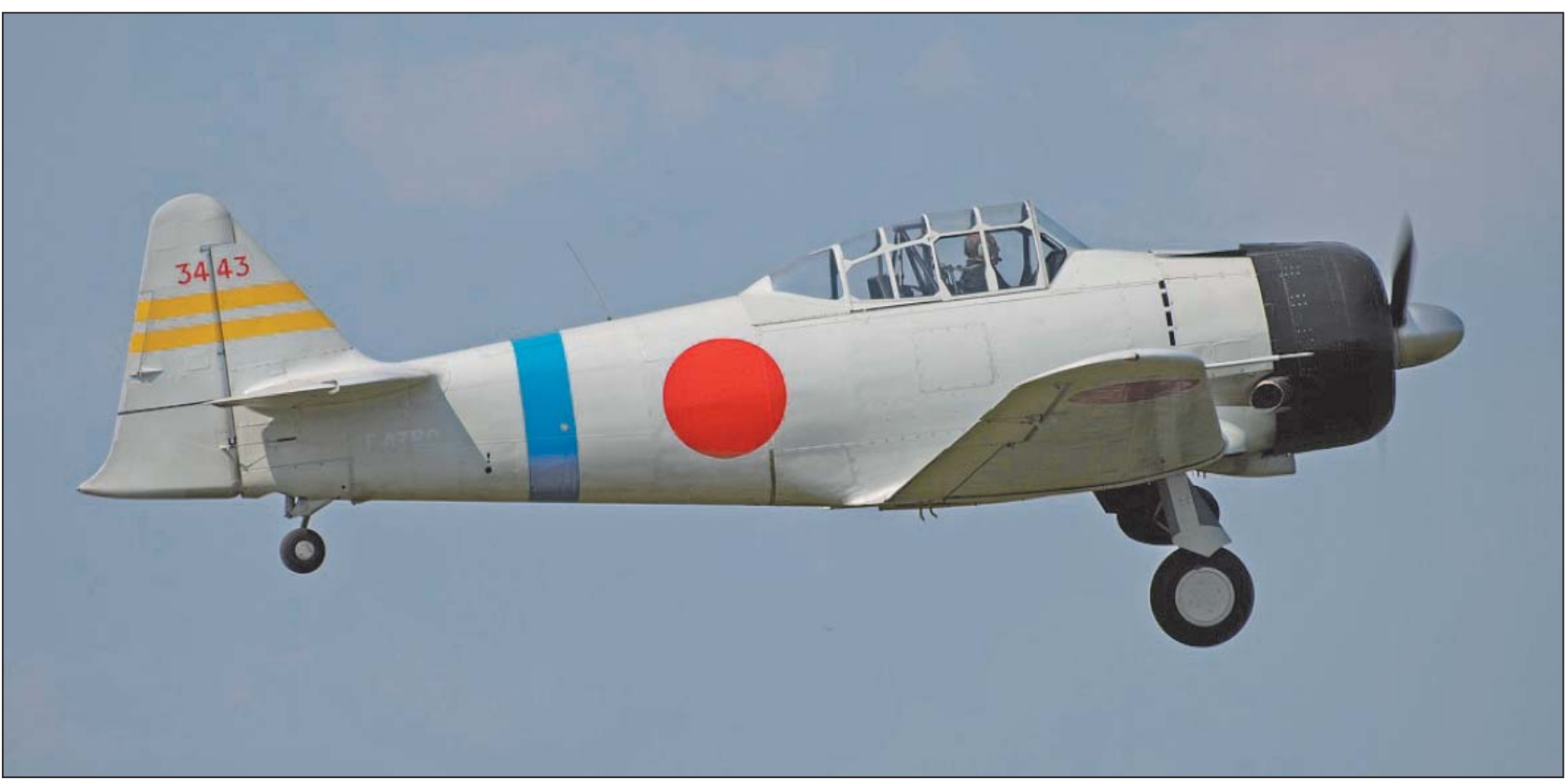

\footnotetext{
orcid.org/0000-0001-5881-403X
} 


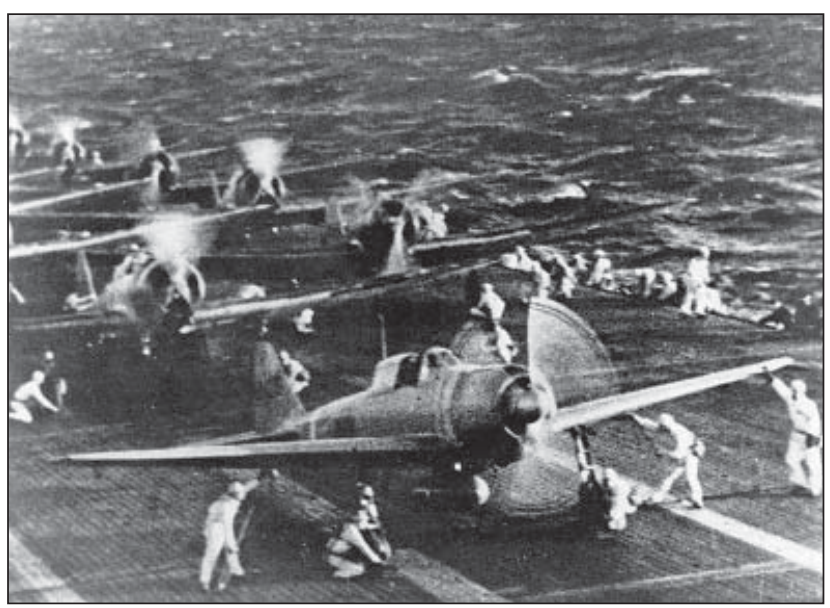

17. ábra. A vadászgépek előkészítése a SHOKAKU fedélzetén, a támadás előtt

Ez megadta a végső lökést: Jamamoto - amellett, hogy a nép és a haditengerészet körében egyaránt népszerű volt - rendelkezett a legnagyobb tudással és tekintéllyel a haditengerészet kötelékében. Nyugdíjba vonulása érzékenyen veszteséget jelentett volna, ezért a vezérkar jóváhagyta a Pearl Harbor elleni támadás tervét. A siker után az admirális még egyszer, utoljára megpróbálta lebeszélni a japán vezetést a háborúról. Tojo Hidekinek írott levelében így fogalmazott:

„Kockázatosnak és illogikusnak tünik nekem az az ötlet, hogy háborút kezdjünk Amerika, Nagy-Britannia és Kína ellen, a négy évig tartó kínai hadmüveletek után, úgy, hogy netán Oroszországgal is harcolnunk kell...llyen esélyekkel szemben, ha a hadba lépés mellett döntünk... én mint a flottáért felelös szakember vajmi kevés reményt látok a sikerre, ha közönséges stratégiát követünk."

A terv jóváhagyása után talán a legnagyobb problémát Nagumo személye jelentette. Politikai nézetei szöges ellentétben álltak a Jamamoto által képviselt tendenciákkal: szerinte Japánnak joga van fenntartani a legnagyobb flottát a Csendes-óceánon, s ebben a nyugati hatalmak sem akadályozhatják meg. Jamamoto viszont mindig támogatta a barátságot az USA-val és Nagy- Britanniával, mert tisztában volt vele, hogy egy Nyugat elleni háború Japán törvényszerü vereségéhez vezetne, ezért tartotta magát a tengerészeti megállapodásokhoz. Nem voltak barátok: még Nagumo katonai képességeiről is negatív véleménye volt, ami csak erősödött, amikor megtudta, hogy nem hisz a terv sikerében. Mégsem távolíthatta el: tiszteletben kellett tartania a haditengerészeti hierarchiát.

Október 29-én a vezérkar beiktatta a tervet a háborús parancsok közé. A támadás időpontját hawaii idő szerint december 7-ére tették (az időpont meghatározásában figyelembe vették az időjárás tényezőit, az üzemanyag mennyiségét, valamint azt az információt, hogy az USA csendes-óceáni flottája minden szombat éjjel és vasárnap reggel Pearl Harbor kikötőjében tartózkodik). De volt egy fontos kikötés is: ha a diplomácia sikerrel jár december 1. előtt, lefújják az akciót. Azon túl nincs visszaút: „Minden az istenek kezében lesz" - mondta Jamamoto.

A Pearl Harbor elleni támadásban a tengeralattjáró-flotta is részt akart venni, frissen kifejlesztett, kétszemélyes zseb-tengeralattjáróival, amikre egyenként két torpedót lehetett szerelni. Az admirális azonban tartott attól, hogy ezek jelenléte meghiúsítaná a váratlan támadást, hiszen a zseb-tengeralattjáróknak Pearl közvetlen közelébe kellet behatolniuk, s az amerikaiak felfedezhették őket.

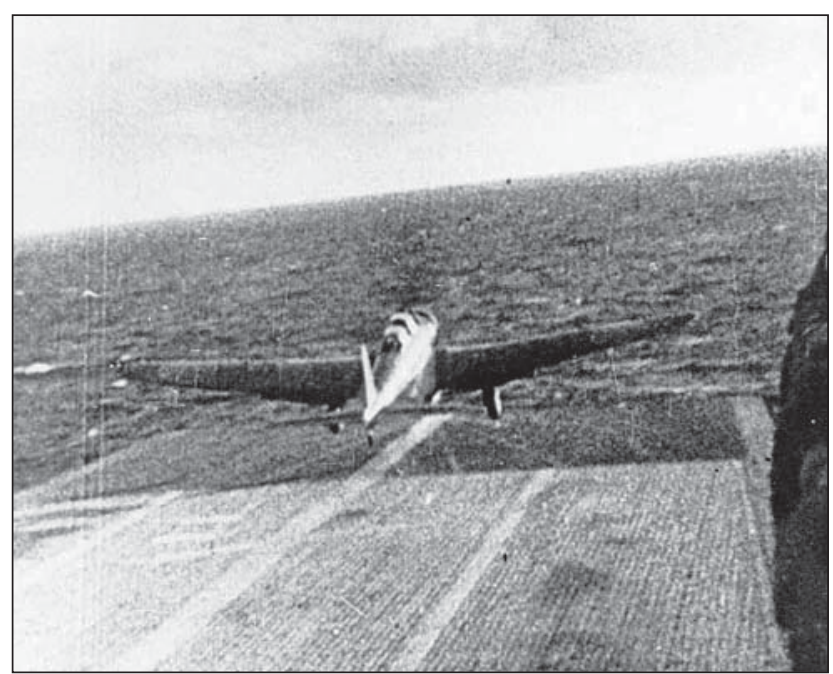

18. ábra. Egy Nakajima-B5N torpedóvető startja a SHOKAKU fedélzetéről

Végül - a tengeralattjárók legénységének lelkesedését látva - engedélyezte, hogy Naodzsi Ivasza kapitány vezetésével akcióba lépjenek, bár közölte velük:

„Ha bemennek az öbölbe, soha többé ki nem jönnek onnan, s az öbölbe való behatolás nem is feltétlenül szükséges...".

Jóslata a támadás során beigazolódott: a zseb-tengeralattjárókat felfedezték, 10 tengerészből csak egy maradt életben, ő is hadifogságba került.

November 5-én Jamamoto kiadta az I. sz. hadműveleti parancsot:

„Keleten megsemmisítjük az amerikai hajóhadat...elvágjuk hadmüveleti és utánpótlási vonalaikat a Távol-Keleten. Győzelmünkkel megtörjük az ellenség harci szellemét."

November közepén a NAGATO fedélzetén jelentette be a tervet tisztjeinek. Mint mondta: Japánnak nagy győzelemre van szüksége, ha nagyhatalomként akar kikerülni a háborúból.

November 22-én a hawaii csapásmérő erők összes japán hajója (beleértve a 6 hordozót is) megérkezett a Kurilszigetekhez, a Hitokappu-öbölbe. November 25-én Jamamoto elrendelte:

„Az operatív egység a legnagyobb titokban...vonuljon a hawaii vizekre, s a hadmüvelet bejelentésének pillanatában rohamozza meg az amerikai flottát, s mérjen halálos csapást rá. Az első támadásra „X-nap” hajnalán kerül sor.”

Másnap a flotta hajói egyesével nekivágtak az útnak. Az AKAGI, a KAGA, a SHOKAKU, a ZUIKAKU, a SORYU és a

19. ábra. Egy Nakajima-B5N akcióban: a háttérben Hickam Field és a lángoló amerikai hajók

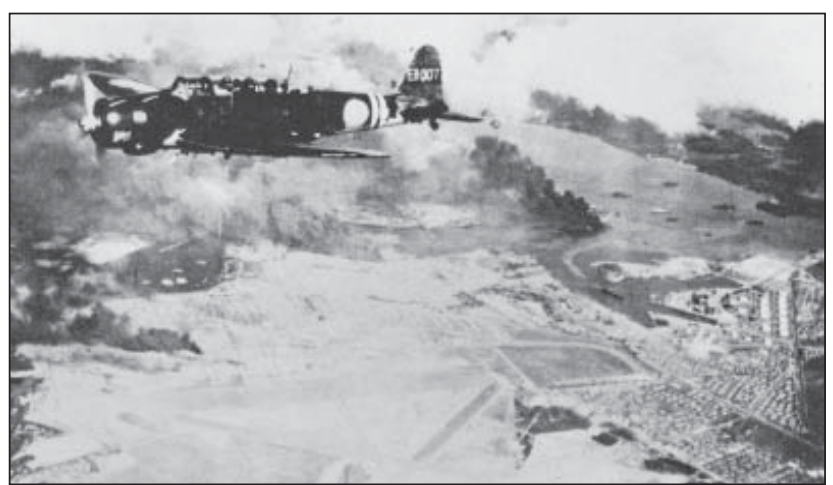




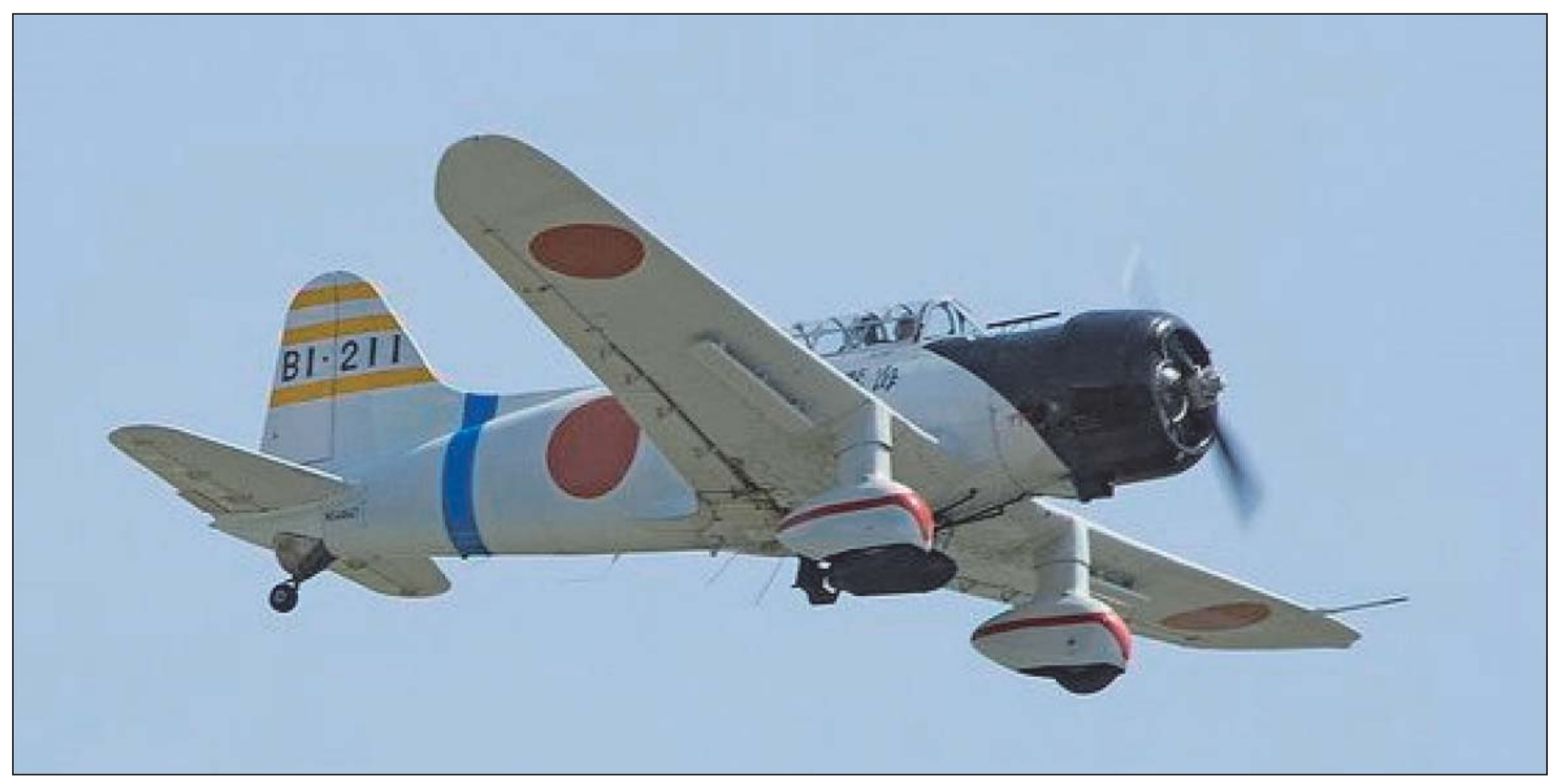

22. ábra. A Pearl Harbort támadó japán kötelékekben az Aichi D3A (Val) volt az uralkodó zuhanóbombázó típus (A képen replika látható.) (Fotó: K.I.)

gót, amelyet Togo admirális használt a csuzimai csatában, Jamamoto pedig elküldte utolsó üzenetét az egész flottának: „Ettöl a csatától függ Birodalmunk felemelkedése vagy bukása. Mindenki tegye a kötelességét!"

\section{„LÉGitámadás, Pearl Harbor. . .EZz nem gyakorlat. . . ."}

1941. december 7-én a Csendes-óceán északi részéről közeledett a japán csapásmérő erő. A pilóták hajnali négy óra körül már talpon voltak: készültek a támadásra. Ekkor kb. 325 mérföldre voltak Oahu partjaitól. A rádiósok egész éjjel a honolului rádió adását hallgatták: semmi jele nem volt annak, hogy az amerikaiak bármit is gyanítanának. Hat órakor megkezdődött a repülők útra bocsátása: először a Zérók szálltak fel, amelyek ekkor a világ talán legjobb vadászgépének számítottak, majd a japán hordozókat védelmező harci járőrök. Ezután következtek a magasbombázók, a torpedóbombázók és a zuhanóbombázók: csakhamar a támadás első hulláma, 183 gép volt a levegőben. 20 perc alatt alakzatba rendeződtek, s megindultak az Oahu sziget felé. Az amerikaiak semmit sem gyanítottak a bázison, pedig voltak jelek arra, hogy valami készülhet. A WARD nevű romboló elsüllyesztett két zseb-tengeralattjárót a kora reggeli órákban, mégsem történt semmi.

Reggel 7 óra után pár perccel a japán hordozókról a magasba emelkedett a támadás második hulláma: 54 horizontális bombázó (amelyeknek a Hickam és Kaneohe repülőtérre, illetve Fort Islandra kellett lecsapniuk), valamint 78 zuhanóbombázó és 36 kísérő vadászrepülőgép indult meg Pearl Harbor ellen. Összesen 353 gép támadott a két hullámban.

Aznap reggel Washingtonban Marshall tábornok információkat szerzett a Japánban zajló készültségről, s ezeket a haditengerészet kódfejtői is megerősítették. Ezért Marshall üzenetet küldött Hawaiira:

„A japánok keleti standard idő szerint délután egy órakor ultimátumot jelentenek be, ezen kívül parancsra elpusztítják a kódgépeiket. Hogy milyen jelentősége van ennek, azt nem tudjuk, de mindenesetre legyenek riadókészültségben..."
Az üzenetet azonban nem látták el sürgősségi jelzéssel, így Hawaiion félretették rutinkézbesítésre. Ha az üzenet eljutott volna Kimmel parancsnokhoz, talán másképp alakulnak a dolgok. De nem ez volt az egyetlen véletlen azon a vasárnap reggelen: az Opana mozgó radarállomáson szolgálatot teljesítő két katona észlelte a japán gépeket. Körülbelül 50 mozgó pontot láttak a radaron, ezt azonban nem közölték az információs központtal, ahol úgy gondolták, saját B-17-es különítményük érkezik. Az amerikai gépek száma azonban csak húsz körül mozgott; ha tudatják, hogy mintegy 50 radarpontot észlelnek, az információs hadnagy biztosan észbe kapott volna. Ezzel az információval azt is megtudták volna, merre vannak a japán hordozók. Ezek a véletlen tényezők azonban nem keltettek feltűnést Pearlben: a támadás előtt Kimmel tengernagy legnagyobb gondja ezen a reggelen a Short ezredessel vívandó golfjátszmája volt.

7 óra 49 perckor Fucsida parancsnok megbizonyosodott arról, hogy Pearlben senki nem sejt semmit: tökéletes a meglepetés, a támadás kezdetét veheti. Néhány perc múlva leadta a várt kódot Nagumonak: „Tora! Tora! Tora!”, azaz háromszoros „tigris”, hogy a japán gépek megkezdték a feladat végrehajtását.

$A z$ egyesített flotta japán horgonyzóhelyénél, Hasiradzsimánál Jamamoto épp shogit játszott Ugaki vezérkari főnökkel, amikor megkapták a hírt: megindult a Pearl Harbor elleni támadás. Ugaki izgatottan a hadműveleti szobába ment, Jamamoto viszont teljesen nyugodt maradt.

Az első támadás a nyugati part ellen irányult, a Kaneohe repülőtér ellen, majd Ewa Field felé vették az irányt a Zérók. Itaja korvettkapitány, a Zérók vezérpilótája így emlékezett vissza:

„Pearl Harbor még mindig aludt a reggeli ködben. A kikötöben nyugalom és csend honolt, még füstjelet sem adtak az oahui hajók. Látszottak a szépen elrendezett barakkcsoportok...az autóút fehér vonala...öt támadási célpont minden irányban. Egy vonalban ezekkel, a kikötőben a csendes-óceáni flotta fontos hajói álltak szorosan egymáshoz rögzítve." 


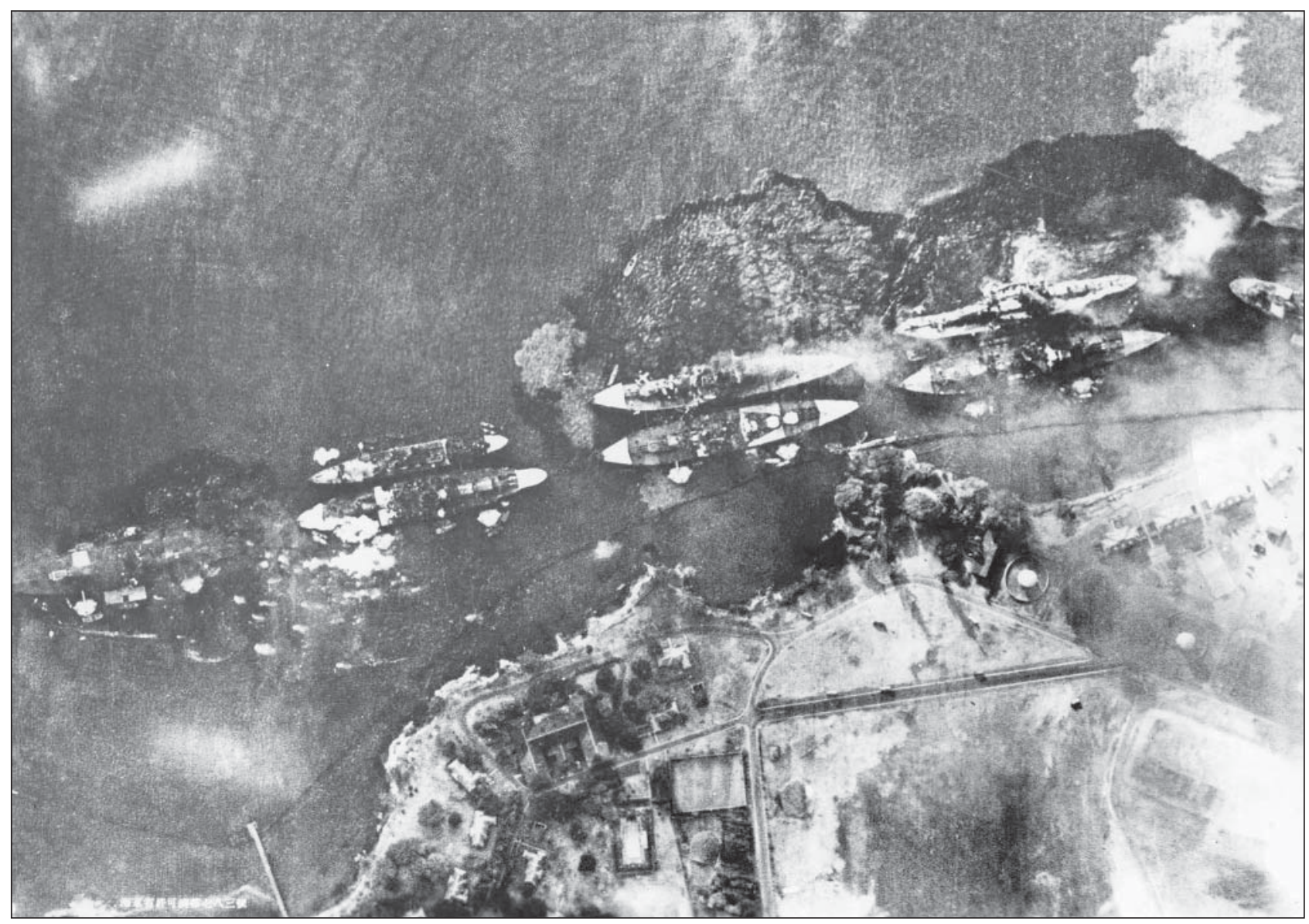

23. ábra. Amerikai hajók egy japán pilóta szemszögéből

Hickam Fieldnél a Zérók a szorosan, szárnytól szárnyig egymás mellé állított B-17-esekre koncentráltak: több mint a felét sikerült megsemmisíteni, s az alapvető létesítményeket is komoly találat érte. Wheelernél is siker koronázta a támadást: a légvédelmi ágyúk nem viszonozták a tüzet, s egyetlen amerikai repülőgép sem szállt fel. Teljes volt a meglepetés...

A támadás fő célpontjai ezután következtek: a WEST VIRGINIA volt az első hajó, amit találat ért. Oldalra dőlt,

\section{4. ábra. A pusztítás mértéke: a USS DOWNES romboló} fedélzete a támadás után

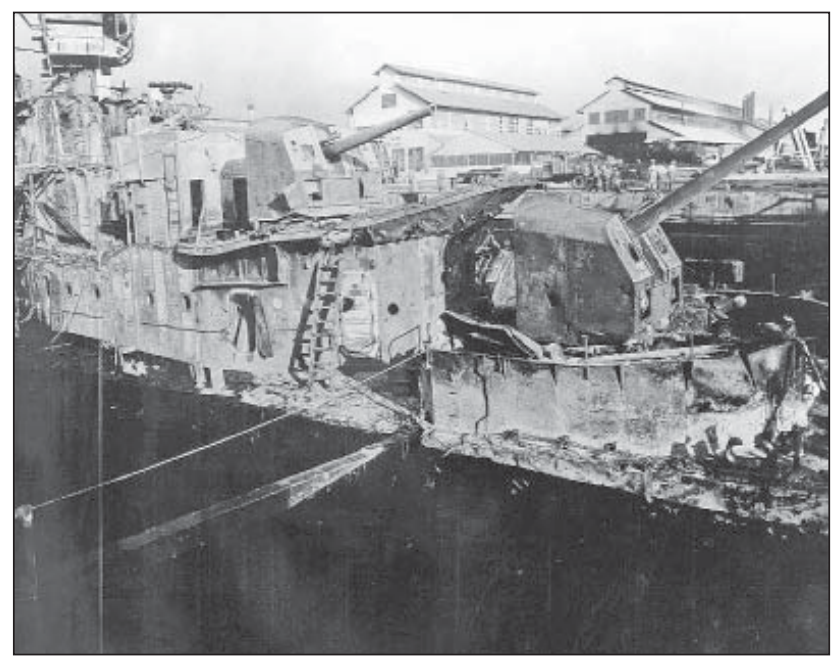

majd elsüllyedt: két tiszt és a legénység 103 tagja veszett oda. Az OKLAHOMÁT három torpedótalálat érte, s megdőlt. Az ARIZONÁT bombatalálat érte: az elülső lőszerraktárban robbant fel, teljesen szétroncsolva a hajó elejét. Olyan gyorsan süllyedt el, hogy még felborulni sem volt ideje: a legénység négyötöde veszett oda, több mint ezer ember szorult a fedélközbe. A TENNESSEE fedélzetén a legnagyobb károkat az ARIZONÁRÓL lehulló, égő törmelékek okozták. A NEVADA és a MARYLAND két másik hajó-

25. ábra. Egy becsapódott japán vadászgép maradványa a USS CURTISS fedélzetén

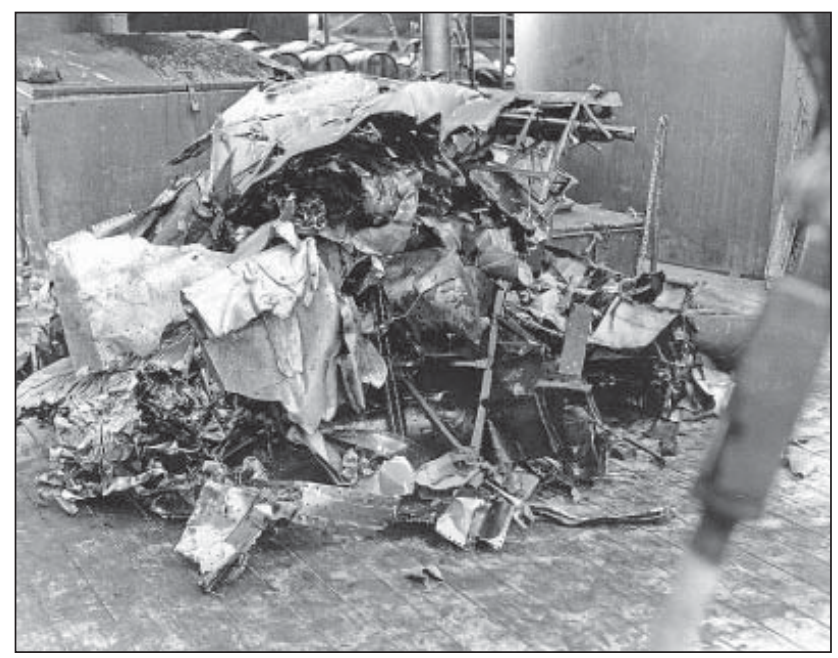




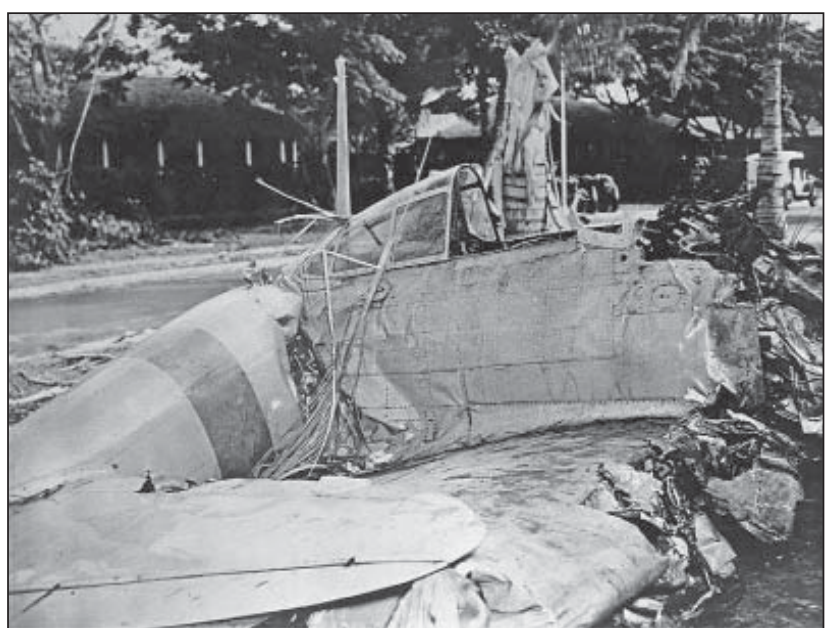

26. ábra. Egy Zero maradványai

hoz volt rögzítve, így nem érte őket végzetes kár. A CALIFORNIA, a flotta anyahajó-rajának zászlóshajója két torpedótalálatot kapott. A PENNSYLVANIA, a Csendesóceáni flotta zászlóshajója a szárazdokkban volt, légvédelmi ágyúit fel tudták használni a Zérók ellen. Feltűnő volt, hogy a támadás során a japán harci gépek olyan biztonsággal repültek rá a célpontokra, mintha hazai gyakorlóterep fölött lettek volna. Ez azzal magyarázható, hogy a szigeten élő japán parasztok a kikötőhöz közeli cukornád ültetvényeken 4-5 m széles és 30-40 m hosszú csapásokat vágtak, amelyek a levegőből nézve, mint hatalmas nyíljelzések mutattak a célpontok irányába.

8 óra 30 perckor - keleti idő szerint 13 óra 30 perckor - a támadás híre elérte Washingtont, éppen amikor a japán nagykövetek átadták a béketárgyalásoknak véget vető üzenetet a külügyminisztériumban. Hull, amerikai külügyminiszter nem tudott a támadásról, így durván elküldte a japán nagyköveteket. Hamarosan minden rádióállomás megszakította adását, s bejelentették: Pearl Harbort megtámadták a japánok.

Mire az első hullám célba ért, a második hullám még csak félúton járt: 54 magasbombázó kapta feladatul Hickam, Kaneohe és Fort Island végső megsemmisítését, 35 Zéró biztosította számukra a védelmet. 8 óra 50 perckor kezdődött a második hullám támadása. Közben a Wheeler Fieldnél két amerikai gépnek sikerült felszállni, s megsemmisíteni 7 ellenséges gépet. Mire a második hullám elkezd-

\section{7. ábra. A támadás civil áldozatokat is követelt}

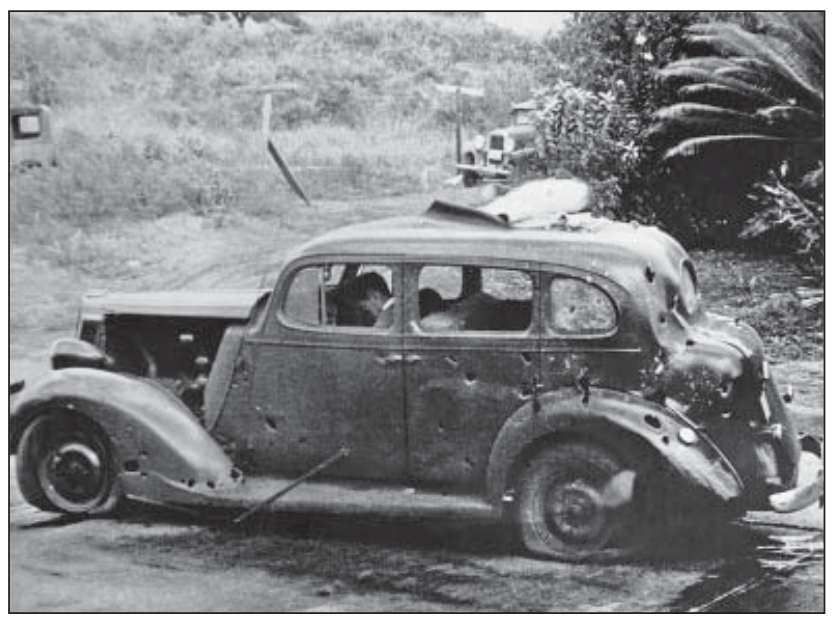

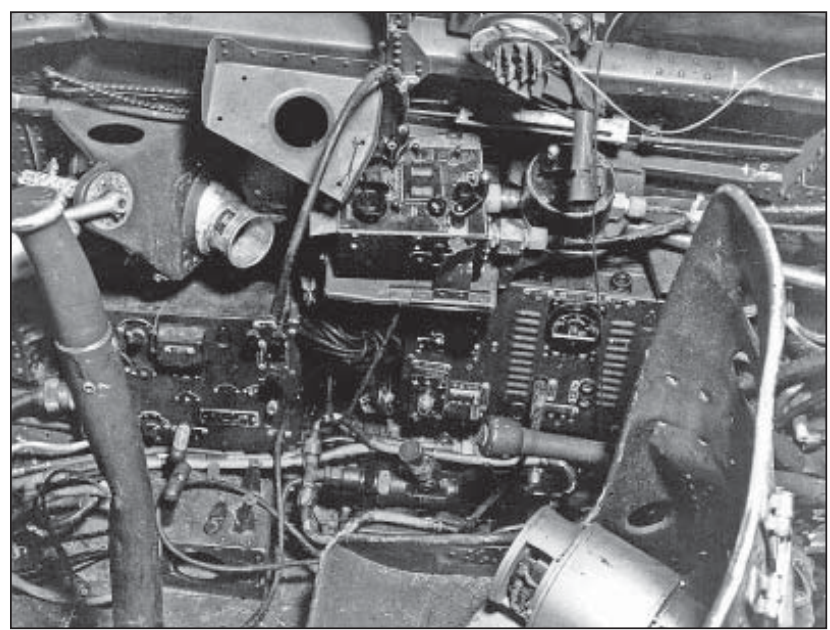

28. ábra. Egy lezuhant Zero pilótafülkéje

te a feladat végrehajtását, az amerikai védelem némileg megerősödött.

A támadás végén Fucsida parancsnok felmérte az amerikaiak veszteségét: nyolc csatahajó, három könnyűcirkáló, három romboló, négy segédhajó. Ezzel szemben a japánok mindössze 29 repülőgépet, egy nagy tengeralattjárót, s öt zseb-tengeralattjárót veszítettek. A japán pusztítás azonban nem volt olyan mértékü, mint ahogy azt Jamamoto remélte: két csatahajó elvesztése és hat másik harcképtelenné válása nem bénította meg az USA haditengerészetét. A flotta három repülőgép-hordozója (a SARATOGA, az ENTERPRISE és a LEXINGTON) ugyanis a támadáskor nem volt ott Pearl Harborben, pedig ezek elpusztítása nagyobb előnyt jelentett volna. Az is fontos tény, hogy a japánok nem támadták meg a Hawaii szigetek olajraktárait, pedig ezzel valóban hónapokra sikerült volna megbénítani a flottát.

Bár Jamamoto valóban korának talán legnagyobb haditengerészeti zsenije volt, a Pearl Harbor elleni támadás koncepciójának megvoltak a maga hibái. Úgy vélte, hogy egyetlen, meglepetésszerű támadás elég a háború eldöntéséhez. E hitét támasztotta alá személyes tapasztalata, a Tsushimánál aratott nagy győzelem. Megrögzött szerencsejátékosként tervét hazárdjátékként is felfoghatjuk: a csapásmérő erők hordozóit könnyen bemérhették volna, a táma-

29. ábra. Díszlövések 1941. december 8-án, a támadás során megölt 15 amerikai tiszt temetésén

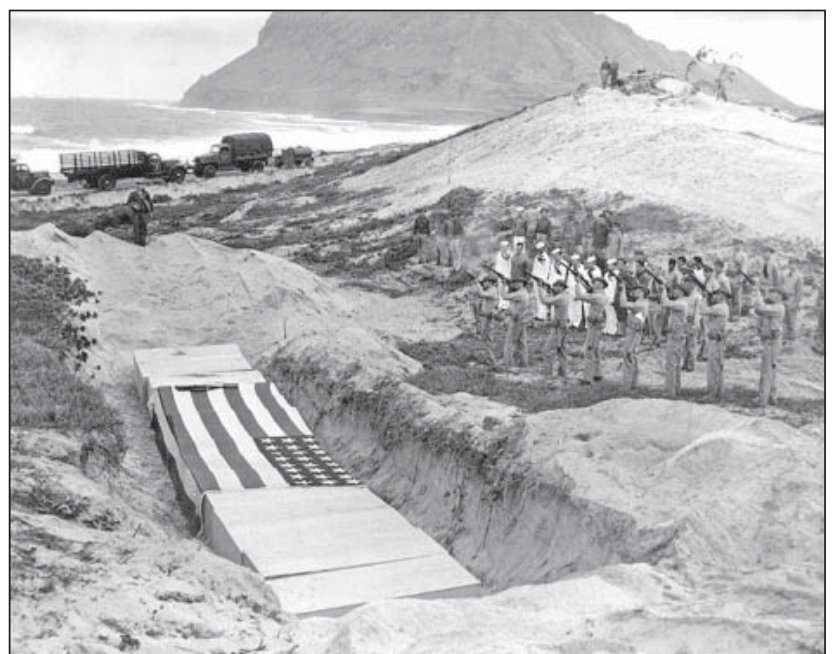




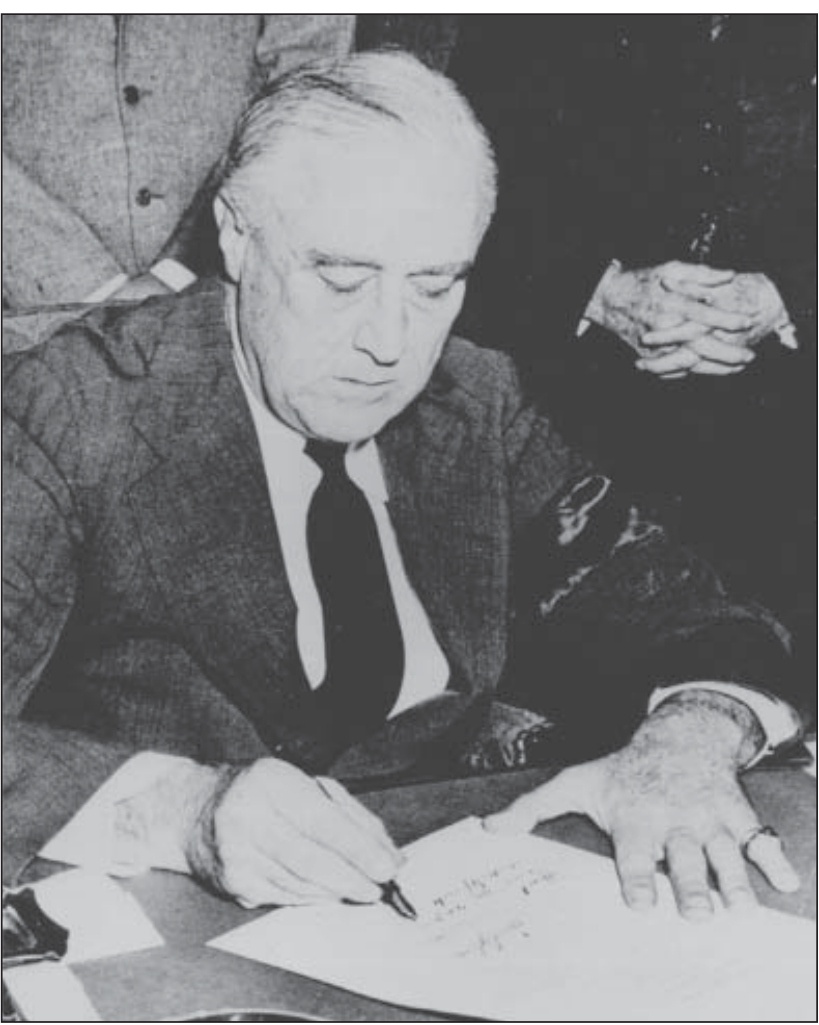

30. ábra. 1941. december 8-án Franklin D. Roosevelt, amerikai elnök aláírja a Japán elleni hadüzenetet, amivel az USA hivatalosan belépett a második világháborúba

dó repülőket is felfedezhették volna a radar segítségével. Csak a szerencsén és a véletlenek sorozatán múlott, hogy nem így történt. Mint a legtöbb japán terv, ez is rendkívüli mértékben komplikált volt, sikere a tökéletes kivitelezéstől függött. Ezt azonban már a hírszerzés munkája megkérdőjelezte: a japánoknak fogalmuk sem volt róla, hogy a csendes-óceáni flotta hordozói Pearl Harborben vannak-e vagy sem. A támadás során csak a cirkálókra, a csatahajókra és a hordozókra koncentráltak, pedig a gép- és olajraktárak elpusztításával komoly nehézséget okozhattak volna a csendes-óceáni flottának. A fegyverek és az utánpótlás így sértetlen maradt, ami lehetővé tette az amerikai flotta gyors regenerálódását.

Japán célja az volt, hogy az USA belássa egy hosszú és nehéz háború céltalanságát. A felbőszült Amerika azonban éppen fordítva reagált: a támadás másnapján hivatalosan is belépett a második világháborúba. Találó volt Jamamoto megjegyzése Pearl Harbor után:

„Azt hiszem, csak fölébresztettük az alvó oroszlánt."

\section{EPILóGuS}

1941. december 7. a „szégyen napja”-ként vonult be az amerikai történelembe, Japán számára viszont a dicsőség kezdetét jelentette. Pearl Harbor után minden terv szerint haladt: 1942 márciusára jelentős területeket foglaltak el a Csendes-óceán térségében. Ez a dicsőség azonban kérészéletűnek bizonyult: oka volt ennek az amerikai termelékenység megmutatkozása, de legfőképp a japán katonai vezetők hódítási vágya. Az eredeti terv szerint 1942 márciusában felfüggesztették volna a terjeszkedést, hogy biztosítsák az addig megszerzett területeket, de ehelyett a további expanzió mellett döntöttek. Ez végzetesnek bizo- nyult: Midwaynél a japán erők jelentős amerikai ellenállásba ütköztek, s a háború során először kényszerültek viszszavonulásra.

A csendes-óceáni háború további eseményei Jamamotót igazolták: Japán nem kerülhetett ki győztesként az elhúzódó háborúból. A tehetséges flottaadmirális azonban már nem érte meg, hogy jóslata valósággá váljon: 1943. április 18-án, Bougainville fölött amerikai légitámadás áldozata lett, P-38-as gépek lelőtték a G4A (Betty) bombázógépet, amelyen utazott.

Iszoroku Jamamoto a hazaszeretet szimbólumaként él a japán nép körében. 1958-ban szülővárosában, Nagaokában emlékparkot hoztak létre a nagy flottaadmirális tiszteletére, de az iránta érzett megbecsülés napjainkig sem csorbult. 1999-ben nyílt meg Nagaokában az Iszoroku Jamamoto Múzeum, amelynek legfőbb célja, hogy bemutassa az admirális személyiségének mindkét oldalát: a hazáját hűen szolgáló katonát és a magánembert az egyenruha mögött. A gyűjtemény részét képezi többek között egy angol nyelvű Biblia, több személyes magánlevél, de fellelhetőek a háborúval kapcsolatos kéziratos munkái és híres szamurájkardja is.

\section{FELHASZNÁLT SZAKIRODALOM}

1. Edwin O. Reischauer: Japán története. Maecenas Kiadó, Budapest, 1995.;

2. Rondo Cameron: A világgazdaság rövid története a kőkorszaktól napjainkig. Maecenas könyvek, Budapest, 1998.;

3. Colcutt-Jansen-Kumakura: A japán világ atlasza. Helikon Kiadó, Budapest, 1997.;

4. Farkas Ildikó: Az ellentmondások földje: Japán. História, 2001/2.;

5. Diószegi István: A hatalmi politika másfél évszázada História-MTA Történettudományi Intézete, Budapest, 1997.;

6. Biography of Yamamoto www.goldenessays.com/ alphabetic/1/biographies/yamamoto.htm;

7. Tora! Tora! Tora! Hadi Krónika, 21. szám;

8. Isoroku Yamamoto: Japan's Unwilling Warrior Pearl Harbor's World War II Collector's Edition - The Official 50th Anniversary Magazine, New York, 1991.;

9. Holmes-Benett: A háborúk világtörténete. Corvina Kiadó, Budapest, 1999.

10. Edwin P. Hoyt: Pearl Harbor. Agora Kiadó, Budapest, 1999.;

11. Ivor Matanle: A második világháború. Merhávia Kiadó, Budapest, 1997.;

12. Endresz István: Kuriózumok az 1939-1945-ös légiháborúból VIII-X. www.altonova.hu/forszazs/ legiero;

13. Végh Ferenc: Pearl Harbour. Haditechnika;

14. Kenneth Macksey: A II. világháború katonai tévedései. Alexandra Kiadó, Pécs, 1996.;

15. N. N. Jakovlev: Pearl Harbor rejtélye. Kossuth Könyvkiadó, Budapest, 1978 ;

16. Rázsó Gyula: Végzetes japán győzelem. História - 1992/2.

17. Ábel András: Los Alamostól Nagaszakiig. Püski Kiadó, Budapest, 1995.;

18. Edwin P. Hoyt: Vér és verőfény. Holnap Kiadó, Budapest, 1992.;

19. Winston Churchill: A második világháború II. Európa Kiadó, Budapest, 1999.;

20. Museum honors man who planned Pearl Attack, www.starbulletin.com/1999/04/14/news/story14.html. 